\title{
Conservation of Historic Sarıer District in Istanbul: Improving the Sustainability and Energy Efficiency of a Bosphorus Village
}

\author{
İstanbul'da Tarihi Sarıer Bölgesinin Korunması: \\ Bir Boğaz Köyünün Sürdürebilirlik ve Enerji Verimliliğinin İyileştirilmesi
}

๑ İpek Zeynep KAPTANOĞLU, ' ๑ Elif MIHÇIOĞLU BILGi'²

Sustainable development has become one of the main global agendas of our time since the 1970s. It is undeniable that people must find a way to live in harmony with their natural and built environments in order to protect the earth in the long term. Recognizing that both heritage and sustainability have crucial importance to society, it is essential to promote sustainability as a critical goal, when certifying the continuity of original characteristics in a historic environment. From this perspective, following a discussion on the theory of these two concepts and the framework of related policies in Turkey, this research analyzes and evaluates the historic Sarıer, composed of Sarıyer and Yenimahalle quarters, two integrated neighbouring Bosphorus villages on the European side of the strait. With an emphasis on sustainability and energy efficiency, this study concludes with environmental and architectural conservation proposals for the study area.

Keywords: Energy efficiency; historic conservation; Istanbul; Sarıer; sustainability.

ÖZ

Sürdürülebilir kalkınma, 1970'lerden bu yana, zamanımızın başlıca küresel gündemlerinden biri haline gelmiştir. Uzun vadede dünyayı korumak adına, insanın, doğal ve yapılı çevresiyle uyumlu bir şekilde yaşamanın yollarını bulması gerektiği inkâr edilemez. Hem miras, hem de sürdürülebilirliğin toplumlar için hayati öneme sahip iki olgu olduğu kabulüyle, tarihi bir çevrede özgün niteliklerin devamlılığını sağlamaya çabalarken, sürdürülebilirliğin de kritik bir başka hedef olarak desteklenmesi gerekmektedir. Böyle bir anlayışla ele alınan bu çalışmada, bu iki kavram, hem kuramsal, hem de Türkiye'deki ilgili politikalar çerçevesinde ele alındıktan sonra, Boğaz'ın Avrupa yakasında yer alan ve günümüzde bütünleşmiş iki komşu Boğaz köyü olan Sarıyer ve Yenimahalle mahallelerinden oluşan tarihi Sarıyer incelenerek değerlendirilmektedir. Sürdürülebilirlik ve enerji verimliliği vurgulu bu çalışma, çalışma alanı için çevresel ve mimari koruma önerileri ile sonuçlanmaktadır.

Anahtar sözcükler: Enerji verimliliği; tarihi koruma; İstanbul; Sarıyer; sürdürülebilirlik.

'istanbul Kültür University Faculty of Architecture, Graduate Program in History of Architecture and Restoration, İstanbul, Turkey

${ }^{2}$ Visiting Research Scholar, GSAPP, Columbia University, NY, ABD

Article arrival date: January 11, 2018 - Accepted for publication: November 28, 2018

Correspondence: İpek Zeynep KAPTANOĞLU. e-mail: izkaptanoğlu@gmail.com

○ 2019 Yıldız Teknik Üniversitesi Mimarlık Fakültesi - @ 2019 Yıldız Technical University, Faculty of Architecture 


\section{Introduction}

In a time when the world's resources are nearly exhausted, just physical conservation cannot be assumed sufficient to protect original historical values and characteristics; but cultural, economic, and ecological balance must also be achieved. Such a goal demands an integrated approach. Thus, this research analyzes and evaluates Sariyer District, a historic area, which also has important natural resources that are thought to be under threat more than ever. In an effort to develop necessary urban conservation proposals with a common research method, though modified according to the unique qualities of this particular case study with a secondary emphasis on sustainability and energy efficiency, with the hope that Sarıer will serve as a sample quarter for other Bosphorus villages suffering from severe urbanization pressure. ${ }^{1}$

The article depends on a master's thesis study submitted to the Graduate Program of Architectural History and Restoration at Istanbul Kültür University in 2014. For this study, a total of 728 buildings were surveyed externally in 2012. In addition, one historic residential building known as 'Çobanoğlu Mansion' with the most common structure of timber skeleton and brick masonry dating back to early 20th century, which is now used for the housing needs of the staff of Tuberculosis Association (Verem Savaş Derneği) was surveyed both internally and externally in 2013. Analytical studies were carried out within the context of putting forward the general characteristics of the study area thoroughly. As the first phase; historic background, socio-cultural and economical structure, physical structure and settlement characteristics, as well as previous conservation studies were examined. As the second phase, environmental data, traffic-transportation analysis, land ownership pattern, historical periods of buildings, number of floors, building use, roof types and covering materials, structural systems and materials, structural conditions, alterations and typological characteristics were analyzed in the study area, as well as the social characteristics of the study area based on the questionnaires asked to the residents, comprising their profile information, housing-family relations, building-working people relations. Then, depending on the physical and social data in hand, the study area was evaluated with an accent on sustainability through a SWOT analyses, followed by the conservation proposals at both environmental and architectural scales, emphasizing sustainability and energy efficiency (Kaptanoğlu, 2014: 1-2).

\footnotetext{
1 The author of the master's thesis had the opportunity to work at the office of Dennis Rodwell in Edinburgh, Scotland, who is known to study and write on sustainable urban conservation through an Erasmus summer internship and examined the theory and the practice of sustainable preservation at urban and architectural scales.
}

\section{Sustainability, Conservation, and Historic} Environments

The concept of sustainability emerged in the 1970s from the recognition that unlimited consumption by a rapidly increasing population was putting the world's resources and environment in dire jeopardy. Since then, a united environmental consciousness has brought together conservation organizations, national and international coalitions. The concept of sustainable development was first discussed in a report entitled "Our Common Future" that has since become known as the "Brundtland Report", it was presented to the United Nations Environment and Development Commission in 1987 (Egelston, 2013).

Both ecological and historic site conservation researches hope to develop solutions to the problems of air pollution, unhealthy living spaces, and inconvenient working conditions, as well as the rapid population growth and insensible use of natural resources that occurred in the cities after the industrial revolution. These approaches emerged in historic site conservation in the first quarter of the 20th century, as the starting point of the sustainability movement (Dresner, 2002: 24-25); the goal was to encourage harmony among human beings and their natural and manmade environments in order to safeguard the long-term interests of the planet and its many life forms (Rodwell, 2003: 58). With the Rio Declaration of 1992, the concept of sustainable development was expanded to encompass not only environmental problems, but also certain social and cultural subjects (Günay, 2010: 48). Today, the concept of sustainability is continuously evolving (Baycan, 1999: 36), creating new sub-concepts such as social, ecological, financial, spatial, and cultural sustainability in parallel to contemporary needs (Beyhan, 2004: 14).

Conservation of the ecological balance between people and the physical environment is the core problem now, at this latest level of human cultural development (Kuban, 2010: 260). Historic sites are, one of the most important spatial reflections of human culture. Their conservation serves to sustain the original characteristics of these urban fabrics so that they may be transferred to the future as historical documents and sources of cultural identity. In this context, the concept of sustainability, founded on the notions of continuity and persistence, stands at the very basis of historic preservation (Günay, 2010: 53).

Sustainable development studies are long-term processes that must balance environmental, social, and economic factors to produce new and creative ideas and approaches. For this reason, life habits and production and consumption needs must all be questioned, and studies designed to reduce our ecological footprint should be conducted. In an environmental context, this includes minimizing fossil fuels and increasing renewable energy 
sources, reducing carbon dioxide emissions in cities, reestablishing public transportation systems, reconsidering building construction and management approaches, recycling ecological materials and systems, reconsidering the use of greenspace and water, and re-evaluating any perceived need for increases in spatial quality. Social and institutional innovations can be achieved by fighting unemployment and finding solutions to health and education problems (URL1).

Sustainability is expanding every day. Previously, only environmental issues were addressed; today sustainability has been redefined to encompass current issues such as social justice, population growth, health, education, food needs, the protection of species and ecosystems, industrial development, and the use of efficient energy resources (Dresner, 2002: 67-69).

Energy Efficiency Policies and Energy Efficient Buildings in Turkey

The world's increasing energy needs and limited energy resources have motivated researchers to investigate sources of sustainable energy, highlighting the importance of energy efficiency as a vital component of sustainability. Energy efficiency is defined as the process of improving the productivity of energy use (Fawkes, 2013: 5). In Turkey, radical steps have been taken in the areas of renewable energy and energy efficiency, and necessary restrictions have been in place since 2000 . When the sector-by-sector distribution of energy consumption is analyzed, $30 \%$ of the total energy and $43 \%$ of the electricity consumption in Turkey is used in buildings. Buildings are the second-highest consumer of energy in Turkey, after the industrial sector. Turkey hopes to reduce the amount of energy consumed per GDP by at least $20 \%$, according to values calculated in 2011. Another strategic goal is to make at least one quarter of the 2010 building stock sustainable by 2023. According to the GYODER reports and the building census conducted by the Turkish Statistical Institute (TUIK) in 2000, there are 8 million buildings in stock and 18 million residential units in Turkey. About $50 \%$ of these buildings are over 30 years old and unqualified from the point of energy efficiency, which underscores the importance of implementing energy efficiency practices in these buildings $^{2}$ (Yılmaz Özbağcı, San Akça \& Türkay, 2013: 25-32).

Conversely, none of the related valid Turkish laws (Energy Efficiency Law No. 5627, Reconstruction Law No. 3194, Floor Ownership Law No. 634, etc.), regulations (En-

\footnotetext{
In Turkey, approximately $60 \%$ to $70 \%$ of the electricity is used in household appliances, and $30 \%$ to $40 \%$ is used in lighting. Related data show that houses make substantial contributions to the world's consumption of energy and greenhouse gas emissions. According to a 2009 Energy Saving Conception Survey, $82 \%$ of the energy used in homes is consumed for heat. The ratio of insulated buildings in Turkey is only $20 \%$, and $49 \%$ of houses still use a stove for heating (Yılmaz Özbağcı, San Akça, \& Türkay, 2013: 30-32).
}

ergy Performance Regulation in Buildings Implementing Regulation on Heating and Sanitation, Hot Water Expenditures in Central Heating and Sanitary Hot Water Systems, etc.), communiqués (Communiqué on the Method of National Calculation of Energy Performance in Buildings, Communiqué Pertaining to Training to be Given for Energy Identity Certificates, Educational Institutions and Trainers within the Scope of Energy Performance Regulations, etc.), or Energy Efficiency Strategy Document 2012-2023, address historic or registered buildings (URL2). However, a study conducted in northeast Italy addressed the relationships among energy consumption, the age and the character of existing buildings; in addition, the results indicated that new buildings generally provide for minimum energy requirements and have energy performance certifications. However, old / historical buildings often suffer from high energy consumption (Fabbri, Zuppiroli, \& Ambrogio, 2012). Consequently, sustainable and energy efficient conservation in an historical environment, regardless of its location, is critical.

\section{General Description and Historical Background}

The Bosphorus is an entirely natural waterway that links the Black Sea to the Sea of Marmara and (via the Dardanelles) the Mediterranean. The Bosphorus divides Istanbul into its European and Asian sections, making it the only city in the world to straddle two continents (Deringil, 2006). The strait is approximately 30 kilometres long, general running north-northeast to south-southwest and varying greatly in width, from approximately 700 metres at its narrowest to over 3.5 kilometres at its widest. Its average depth at the centre of the channel is between 50 and 75 metres, but at one point it reaches a depth of over 100 metres. As an international waterway, it is always busy with cargo ships, oil tankers, and ocean liners, as well as with ferries and fishing boats that struggle with the unexpected sharp bends, tricky currents, occasional storms, and dense fog (Sumner-Boyd \& Freely, 2009: 428) (Fig. 1).

Sarıer province covers an area of 151,000 sqm and has the longest coastline on the Bosphorus. The study area, composed of the historic Sarıyer and Yenimahalle quar-

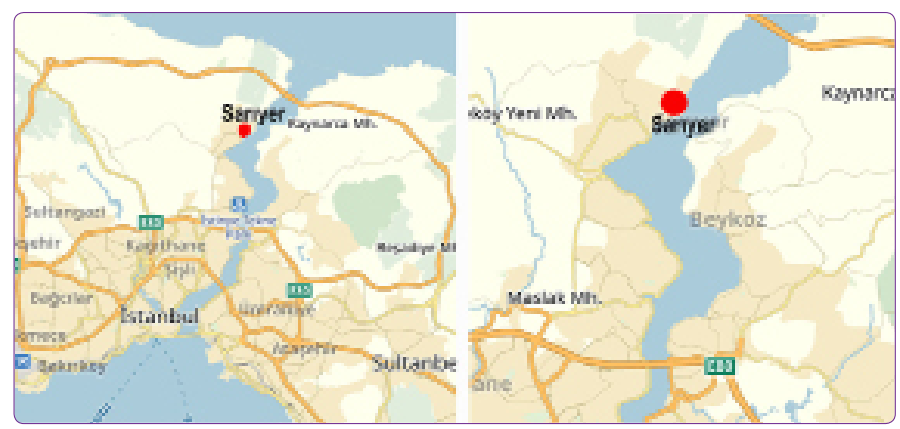

Figure 1. (Left) location of Sariyer in the Bosphorus; (right) Location of the study area in Istanbul (Kaptanoğlu, 2014: 11). 
ters, are the two oldest centres in this province and they cannot be considered separately, as historically they have always been commercially and socially connected (Fig. 2).

Sarıer is topographically flat and located in a valley that was originally a streambed. Situated perpendicular to the coastline, there are many traditional dwellings along. Contrary to Sarıyer, Yenimahalle is located on a sloped volcanic hillside. For this reason, the urban fabric of Yenimahalle gradually rises with the topography, parallel to the coastline. There is also a single row of waterfront houses that runs along the Sariyer and Yenimahalle quarters on the coast of the strait, which is typical for Bosphorus villages.

After the conquest of Istanbul by the Ottomans, the Bosphorus began to flourish. Starting from the $15^{\text {th }}$ century, the villages outside the historic peninsula began to appear (Ülgen, 1996: 127). With migration increasing the population in Istanbul, the Bosphorus villages also started to grow, especially after the $16^{\text {th }}$ century (Balcl, 2006: 9). Sariyer was also started to be used by Ottoman sultans as a vacation destination in summers and as a hunting location in winters (Balcl, 1998: 16). The $18^{\text {th }}$ century saw the construction of palaces, pavilions, and waterside mansions along the Bosphorus for the relatives of sultans and statesmen. It was then, the Levantines and non-Muslims who settled in the region under the permission of the sultan, began to influence the cultural and physical structure of the area. The numbers of hotels, restaurants, and entertainment venues increased with the arrival of foreign scientific and cultural visitors (Mantran, 2005: 285-290). In the $19^{\text {th }}$ century, with the initiation of ferry operations to Sariyer shores and other Bosphorus villages, the general interest in the area for recreational purposes increased (Hürel, 2010: 669). Thus, Sarıyer was transformed into a

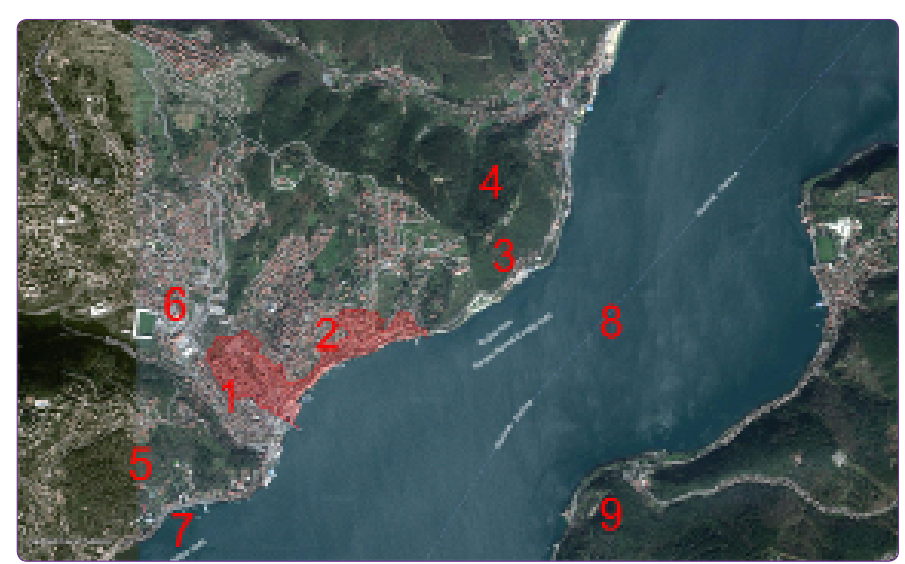

Figure 2. Boundaries of the study area: [1] Historic Sarıer and [2] Yenimahalle. Other important environmental locations outside the study area include: [3] the tomb of Telli Baba, a popular shrine of a Muslim saint for young women to pray, [4] a woodland on the road to Rumeli Kavağı, [5] a woodland belonging to the Russian consulate's summer cottage, [6] the Sarıyer Sports Club's facilities, [7] Mesar Burnu-Piyasa Avenue, [8] Sarıyer waterways used during the fishing season, and [9] Woodland at Anadolu Kavağı (Kaptanoğlu, 2014: 69). traditional neighbourhood that was densely, but modestly occupied until the end of the $19^{\text {th }}$ century (Genim, 2006: 796).

Although as old as Sariyer, Yenimahalle is less frequently mentioned in the literature on the history of the Bosphorus. Since the Byzantine period, it was best known as a quiet fishermen's village and agricultural centre (Hürel, 2010: 669). Inciciyan (1758-1833) described Yenimahalle as the last settlement of summer houses in the 18th century (Inciciyan, 2000: 139). After the initiation of ferry service, Yenimahalle began to see more activity, especially in well-known recreational areas such as Pazarbaşı Fish Pond (known as 'dalyan' in Turkish), Fırıldaklıbahçe Tea Garden, the Music Hall ('Gazino'), public sea baths (originally known as 'deniz hamamı' in Turkish, meaning beach), and Hekimyan's Vineyard (Balcl, 2006: 44, 47) (Fig. 3).

As the number of ferry operations increased for the Bosphorus villages, Istanbul's inhabitants found themselves able to visit the coastline more frequently. Consequently, the villages grew, each becoming dense suburbs of Istanbul (Tutel, 2008: 11-12). The most substantial migrations to Sarıyer were from the Balkans and Black Sea region of Turkey. These began after the Russo-Turkish War in 1877 to 1878 , and increased after the Balkan wars, World War I, and the Turkish War of Independence. During the Ottoman Period, Greeks and Armenians, and to a lesser extent, Jews and Turks, chose Yenimahalle as their summer resort of preference (Balcı, 2006: 23; Mazak \& Mazak, 2008: 20). The number of non-Muslim inhabitants gradually decreased, due primarily to the population exchange in the Early Republican period. However, this fluctuated, depending on the continuing immigration of Greeks and

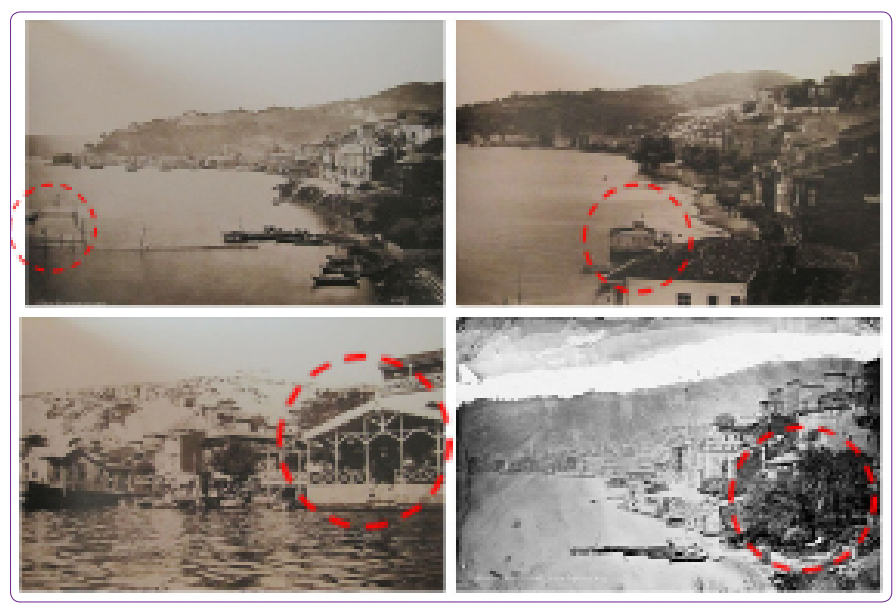

Figure 3. (Top left) Pazarbaşı fish pond in Yenimahalle in 1870 (Genim, 2006: 817; Paskal Sebah, No:16); (top right) Public sea bath (known as 'deniz hamamı' in Turkish) or beach at Yenimahalle in 1920 (Genim, 2006: 829; Anonymous, 1920); (bottom left) a restaurant and Hotel Osmanie in 1890 (Genim, 2006: 827; Anonymous, 1890); (bottom right) A tea garden by the sea in the 1880s (German Institute of Archaeology Archive, Guillaume Berggren). 


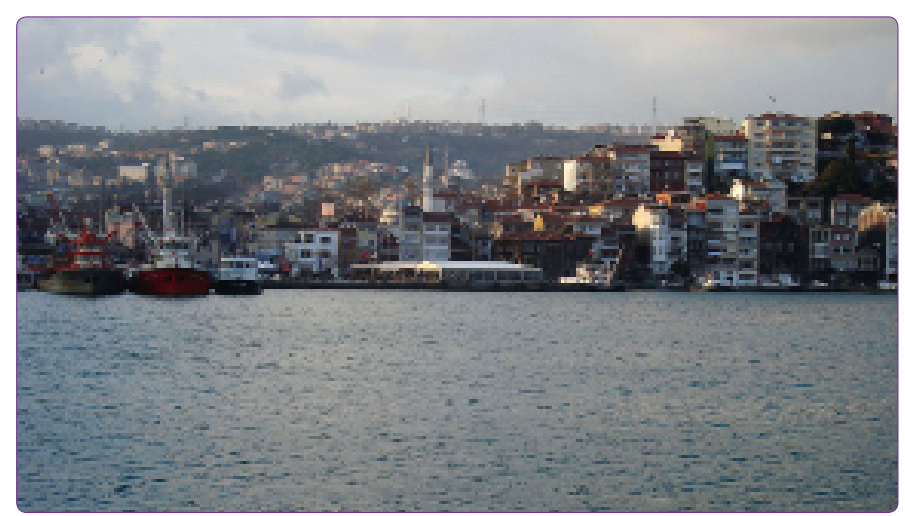

Figure 4. Silhouette of Sarıyer Historic Center in 2014 (Kaptanoğlu Archive, 2014).

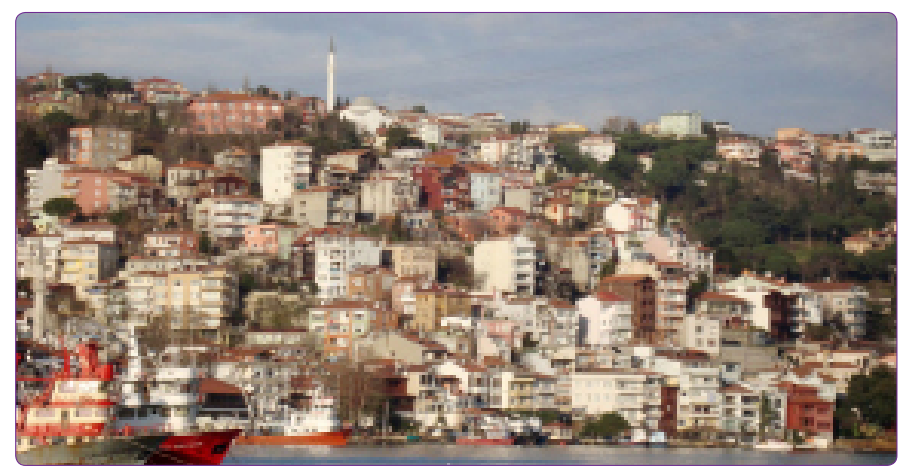

Figure 5. Yenimahalle silhouette from the Sarıyer jetty in 2013 (Kaptanoğlu, 2014: 69).

Armenians to other countries (for political reasons) between 1960 and 1980 (Balcl, 2006: 47).

In time, the waterside houses came to be claimed by the wealthy residents, and the slopes of the Bosphorus were covered with newly-arriving poor squatters. The negative effects of urbanization, together with the low-income neighbourhoods, began to visibly change the natural and the historical fabric of Sarıyer and Yenimahalle, especially after the 1970s (Fig. 4 and Fig. 5).

\section{Environmental Characteristics}

The study area has been registered as both natural and cultural sites. It is quite a desirable area with its proximity to the sea, woodlands, and forests. Parallel to the slightly northern location of the study area, the weather is under the mixed influence of continental climate, which is colder and rainy than Mediterranean climate under the partial influence of Black Sea. With a transitional character in climate, changing from north to south due to the changing precipitation and temperature, the climate, soil and vegetation characteristics are affected. Belgrade Forests close to the study area, constitute an important part of north forests (Başer, 2011: 158-159). The flora of the study area is composed of humid and dense mixed-leaved forests together with the Mediterranean maquis under the effect of both climates. On the other hand, Yenimahalle slopes

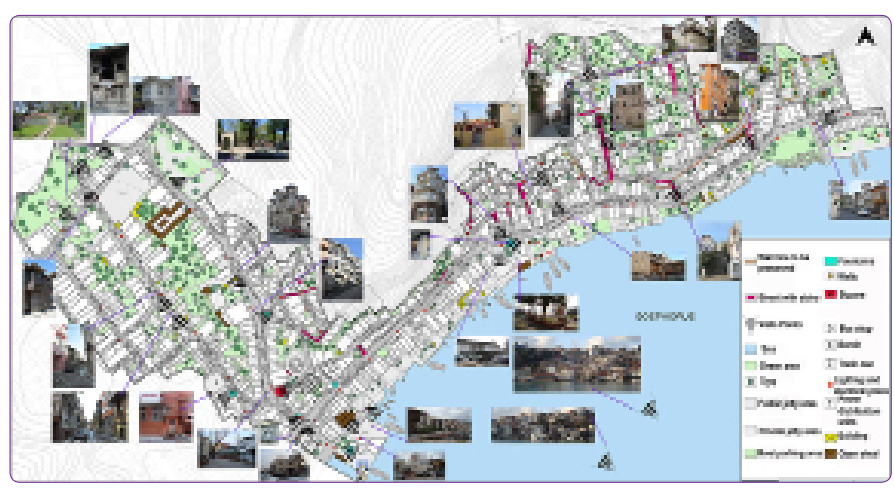

Figure 6. Environmental data analysis (Kaptanoğlu, 2014: 74).

have less soil related with the volcanic features of the land, covered with maquis, Judas Trees (Cercis Siliquastrum), Pistacio Pines (Pinus Pinea) and Cypress Trees (Cupressus Sempervirens), which are also known as the symbolic vegetations of the Bosphorus (Kaptanoğlu, 2014: 32).

Sarıyer also faces the woodlands of Anadolu Kavağı on the Asian side, which is an important natural ecological landscape that enriches the visual quality of the city and the district. The greenery of the cemeteries at the end of Dursun Fakih Street, as well as the parks, other public lawns, and the large gardens of the houses, all substantially increase the rate of greenery in the area. Despite its location along the Bosphorus, public access is limited to only a few points: Taş ískele (Stone Pier) Park, Yenimahalle Park, and Pazarbaşı Park. The rest of the shore is for private use by the waterfront houses, which is the original condition of the Bosphorus coastline due to the ownership pattern (Fig. 6).

The varied topography of the study area is one of its greatest assets. The dead-end streets, streets with stairs, and stone retaining walls that create terraces in steep areas are all typical environmental characteristics frequently seen in Bosphorus quarters. None of the original stone pavements remain in the district. They were of a very rare quality and the stone pavements existed only in certain historic areas of Istanbul. The rest have been changed with asphalt or Ishaped coloured concrete pavement blocks. Traffic congestion and obstructions due to overflow and irregular parking along the main artery are a major environmental problem. The popular coastal roads, running along the Bosphorus on both sides, here named as Yenimahalle and Karakütük Avenues and have frequently heavy traffic. Although located just outside the study area, Telli Baba Tomb is an important node for the area, and a popular religious point of attraction in Istanbul, which also has a direct effect on traffic.

Depending on the comparison of 1950 aerial photo and the latest updated map of the study area used for the analyses; it can be clearly seen that Mesarburnu Pier, the coastal area from Taş i̇skele (Stone Pier) to Ordu Evi (Military Club), as well as Sarıyer Stream (and its branches com- 
pletely) and its mouth at the coastal line where it meets with the Bosphorus, were filled and enlarged in the past years (Kaptanoğlu, 2014: 65, 74).

There are seven historic public fountains in the neighbourhood, dated to the $17^{\text {th }}, 18^{\text {th }}$, and $19^{\text {th }}$ centuries; of which four are still functional.

\section{Architectural Characteristics}

Sarıyer Turkish Bath, the earliest monument in the area, dates back to late $16^{\text {th }}$ or early $17^{\text {th }}$ centuries. Other monumental buildings include; Ali Kethuda Mosque dated to late $17^{\text {th }}$ or early $18^{\text {th }}$ century; St. Prodromus Church built in the $19^{\text {th }}$ century; the Armenian Elementary School and Pazarbaşı Police Station constructed from 1891 to 1892; Sarıyer Pier erected in 1851; and seven fountains. These in- clude the Mesut Ağa Fountain (1645), Ahmet Kamili Efendi Fountain (1812), Sadrazam Haci Salih Paşa Fountain (1822), Çukur Fountain (date unknown), Kaptangazi Fountain (1884), Tekke Fountain (date unknown), and in Yenimahalle the Kaptan-i Derya Hasan Paşa Fountain (1784) (Fig. 7).

The historic residential buildings, dating from the late 19 th to the early $20^{\text {th }}$ centuries, constitute approximately $20 \%$ of all the structures currently standing (Fig. 8). In contrast, the buildings with new structural systems built after the 1970 s (55\% reinforced concrete, $12 \%$ reinforced concrete with timber cladding, which are mostly the reconstructions, $7 \%$ concrete block masonry, and $2 \%$ steel frame) comprise the majority in the area, with $79 \%$ ruining the integrity and authenticity of the historic urban fabric. Early
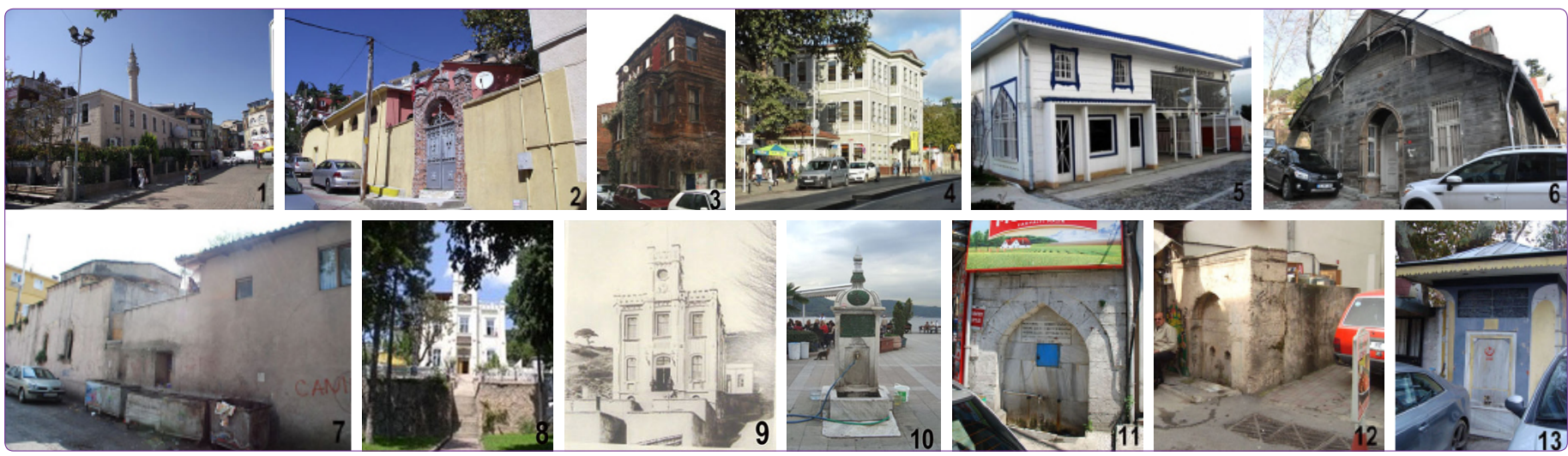

Figure 7. Monument buildings in the study area; [1] Ali Kethüda Mosque at Sarıyer (URL3); [2] St. Prodromus Church (also known as lonnes Greek Orthodox Church) at Yenimahalle (URL4); [3] Hakki Pasha Mansion (Kaptanoğlu archive, 2013); [4] Pertevniyal Valide Sultan Mansion (Kaptanoğlu archive, 2014); [5] Sarıyer Jetty (Kaptanoğlu archive, 2014); [6] Armenian Elementary School at Haydar Doğ Street (Kaptanoğlu archive, 2013); [7] Sarıyer Bath (or Avci Mehmet Bath) (URL5); [8] Pazarbaşı Police Station in the early 19th century (Çiftçi, 599; German Archeological Institute-Yıldız Album) and [9] today (URL6); [10] Ahmet Kamili Fountain in Sarıyer (Kaptanoğlu archive, 2014); [11] Mesut Ağa Fountain (Kaptanoğlu archive, 2014); [12] Hasan Paşa Fountain (Kaptanoğlu archive, 2014); [13] Tekke Fountain in Yenimahalle (Kaptanoğlu, 2014).

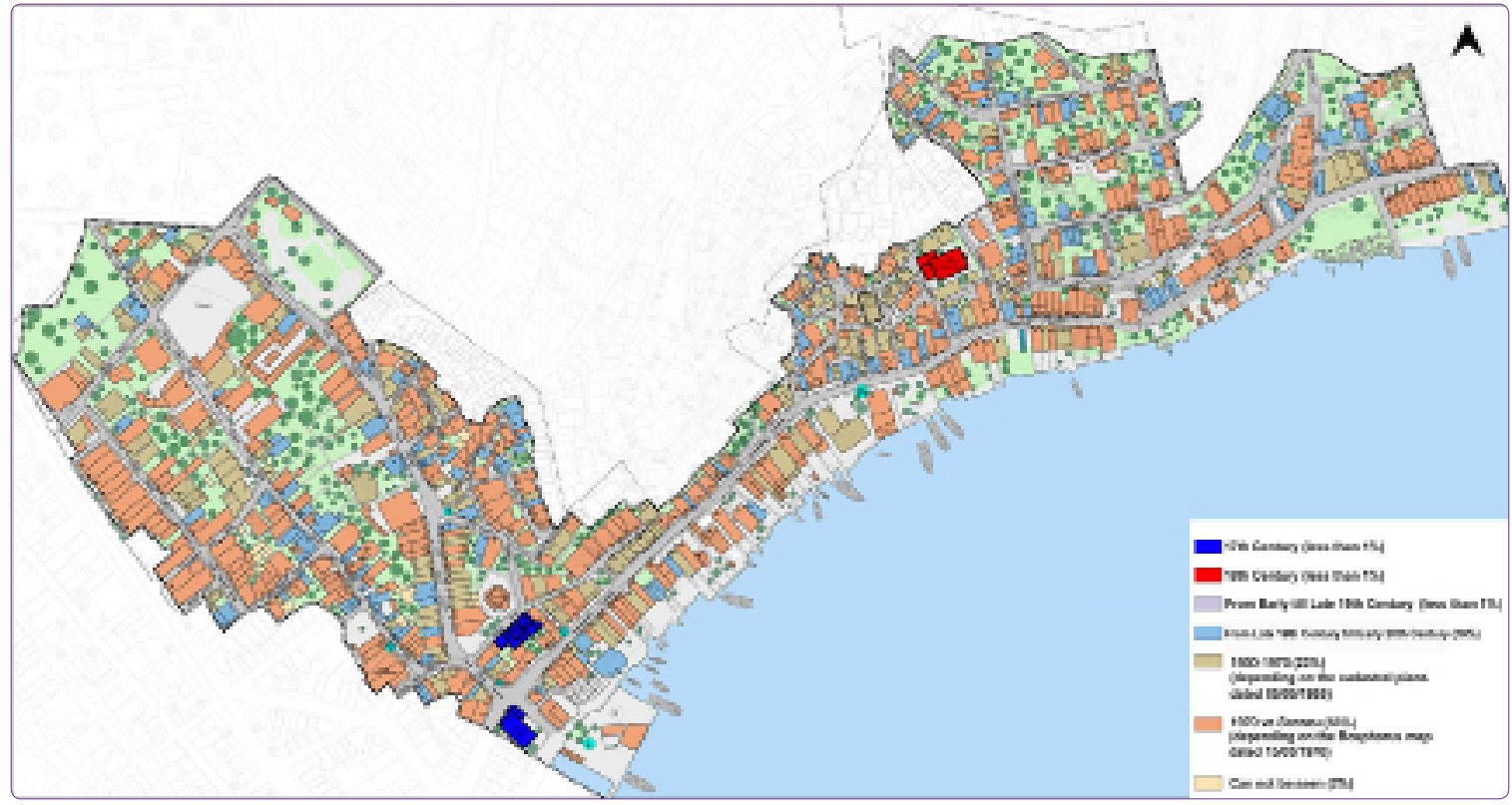

Figure 8. Periodical Analysis of the Buildings (Kaptanoğlu, 2014: 83). 
Republican Period buildings built between 1923 and 1938, with brick masonry and reinforced concrete slabs, constitute a group of compatible structures in the historic area.

In the study area, historic residential buildings are not higher than four storeys (ground floor plus one, two or three storeys) depending on the survey data, which comparatively is lower considering the steep character of the area, since reinforced concrete buildings usually have five storeys or more. This highest group of buildings (ground floor plus four floors and higher) constitute $9 \%$ of the buildings in the study area, but are highly contradictory in terms of the silhouette. It is important to note that $88 \%$ of all the buildings are either completely or partially used (which is a high rate), and $10 \%$ are vacant (these are mostly under construction or ongoing restoration).
Moreover, $87 \%$ of the total number of building lots belong to private owners, and $7 \%$ are owned by the municipality; $63 \%$ are used for residential and $19 \%$ for commercial purposes. Mixed use (commercial on the ground floor and residential on the upper floors) is widespread in Sarıyer; solely residential use is more common in Yenimahalle. In this area, there are different functions such as Turkish baths, manufacturing, healthcare, cultural and educational uses, storage, state administration, association offices, and parking areas (Fig. 9).

Only $8 \%$ of the buildings are original historic traditional buildings with original composite structures: masonry both at their foundation and ground floors, and timber structures at the upper floors (Fig. 10). With regards to structural condition, only about $8 \%$ of the existing his-

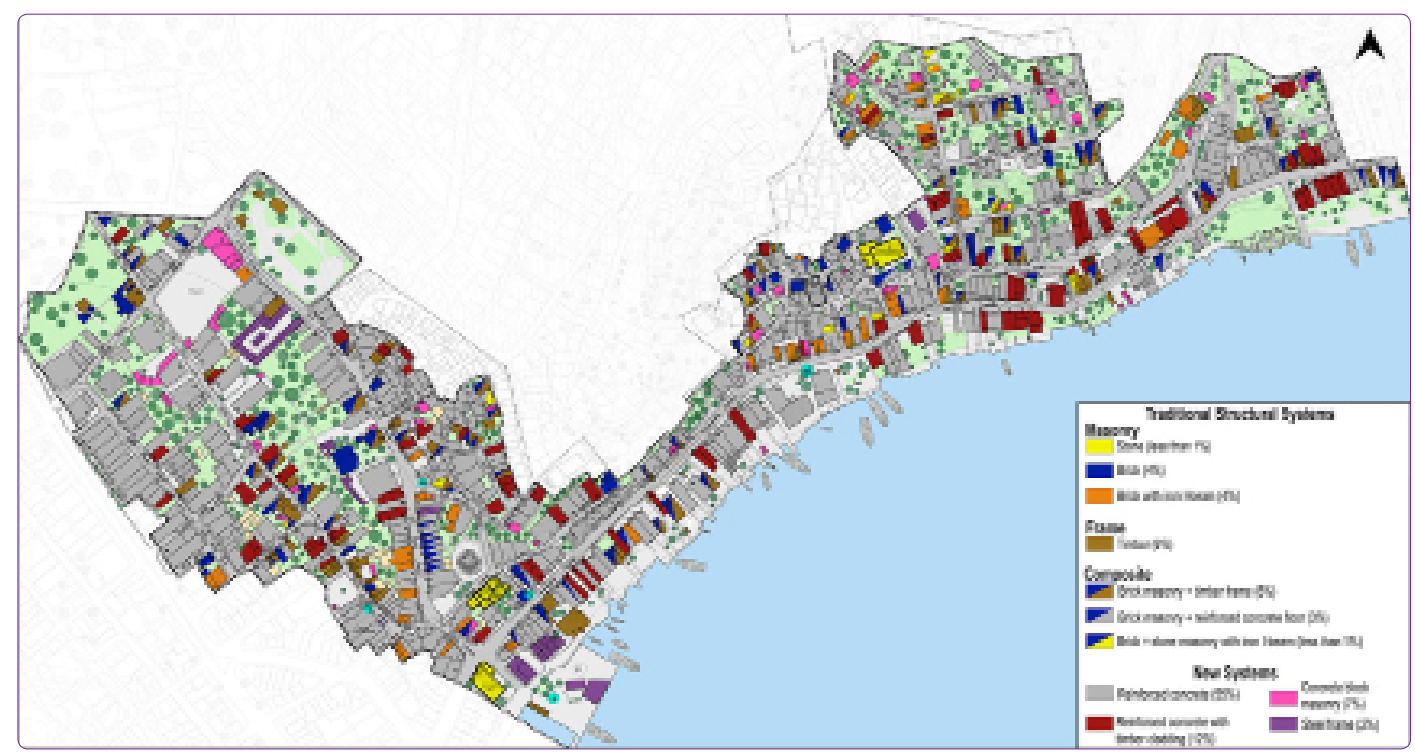

Figure 9. Functional Analysis of the Buildings (Kaptanoğlu, 2014: 94).

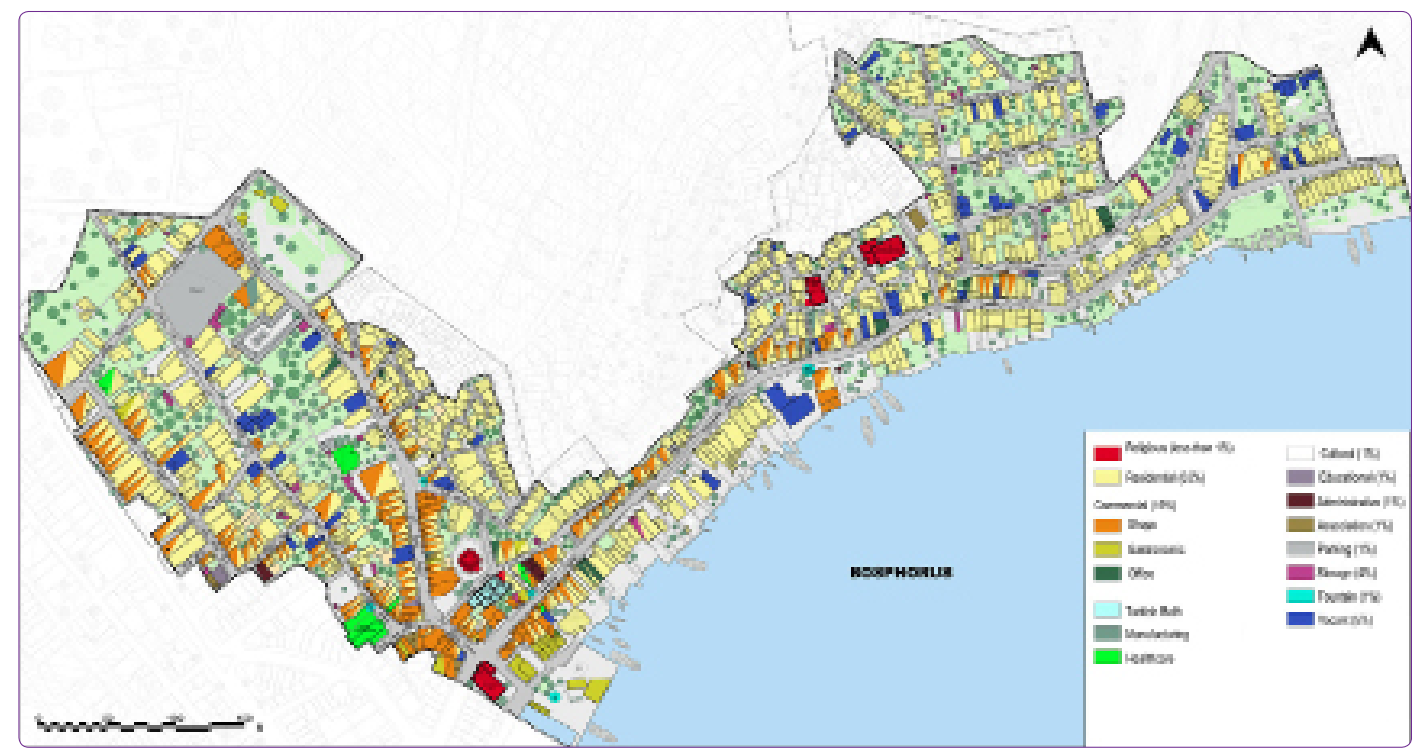

Figure 10. Structure and Material Analysis of the Buildings (Kaptanoğlu, 2014: 99). 
toric buildings are in good condition. Conversely, historic buildings reconstructed pursuant to previous conservation decisions, with reinforced structures and timber façade claddings, comprise approximately $11 \%$ of the buildings; they are mostly differentiated in terms of proportion and have lost their authentic properties completely. With regards to alteration, reconstructed buildings constitute one extreme group; there are no unaltered or completely original historic buildings in the area, which reflects the critical nature of this conservation problem (Fig. 11).

\section{Evaluation of the Study Area}

\section{Values}

Among the strengths of the study area, its rich historic and natural values are the most prominent. In addition to its coastline and location next to a comparatively cleaner sea in Istanbul, as well as its numerous woodlands and forests, its proximity to Belgrade Forest and the fact that

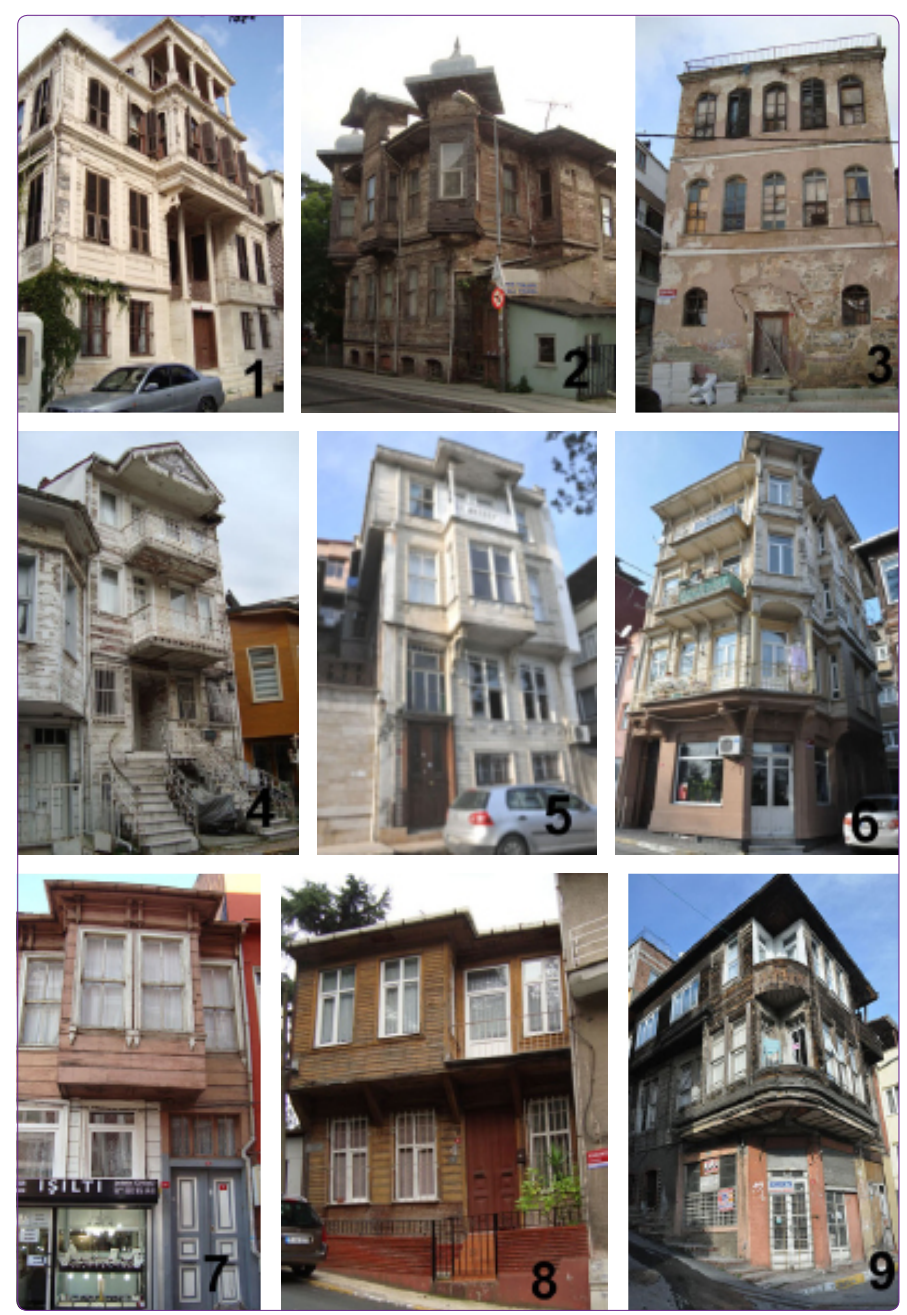

Figure 11. Some examples of historic residential buildings in the study area; [1] Karakütük Street No. 47; [2] Ortaçeşme No. 47; [3] Ocak Ağası Street No. 4; [4] Karakütük Street No. 64; [5] Karakütük Street No. 49; [6] Karakütük Street No. 105; [7] Dursun Fakih Street No.14; [8] Karakütük Street No. 76; [9] Karakütük Street No. 1 (Kaptanoğlu archive, 2014). most of the buildings are located inside gardens or on green lands are important natural values. Most of the historic monuments and residential buildings ( $63 \%$ of the total) in the study area have retained their original function, and $78 \%$ are in use. In addition to its dense green areas, its natural climatic conditions (due to cold winds blowing in the summer) are advantageous, particularly in this region. It is also an important property within the study area because it has kept its original coastline, without any artificial filling. It is an important, positive sign that it is able to continue to use the spring waters coming from the Sariyer hills, even today. Promising conservation efforts in the area include studies conducted to ensure the recycling of domestic waste, and iski's (Istanbul Water Sewage Administration) new collecting units at Baltalimanı that have been implemented to prevent solid and liquid waste from being deposited into the sea. There is also a traditional fishery near the Sarıyer coast, as well as traditional agricultural products being grown in Gümüşdere village nearby.

\section{Problems}

Unfortunately, the inhabitants' lack of an environmental consciousness makes preservation of the natural assets more difficult. Especially where fishing activities are intense, waste materials leaking from boats and contaminants left by cargo vessels transiting the Bosphorus pollute the sea and threaten marine species. Moreover, large-scale sea vessels carrying hazardous materials or fuel, increasing in number every day and effectively trespassing through the Bosphorus (especially those without guide pilots), can cause accidents, threatening safety, life, and property, as well as produce environmental pollution by spilling tons of hazardous material into the sea in this area. ${ }^{3}$

Diminishing spring waters and three non-functional fountains are some indicators of sustainability deficiencies of the local natural water resources. Apart from these, many agricultural lands as a part of open areas have disappeared because of the intense planned and unplanned constructions that took place in this part of Sariyer valley with a dramatic change especially after the 1950s (20102013 İstanbul Bölge Planı Ekleri: 47). Moreover, after it was covered and the road built over it, the natural course of Sarıyer Stream (which used to flow through Sarıyer valley) was gradually disrupted, due to the related rehabilitation works implemented after 2004.

\footnotetext{
The Bosphorus is a a narrow S-shaped channel with several sharp turns and headlands, which prevents a proper lookout. The changing currents makes navigation, especially through dense international shipping traffic, very difficult and risky. Beyond local boats, 60,000 additional vessels transit yearly, of which 5,500 are tankers and heavy cargo vessels carrying hazardous materials. In the last 40 years, there have been 450 accidents resulting in hundreds of casualties, dozens of ships sunk or burned, and thousands of gallons of petroleum products spilled into the sea (Doğan \& Burak, 2007). In 2008, a tanker passing through the Bosphorus struck and damaged buildings along the shoreline at Pazarbaşı in Yenimahalle (Kaptanoğlu, 2014: 142).
} 
Regarding the economics, Yenimahalle and Orta Ceşme Streets, which historically have been used for market purposes, continue to be two important loci for the local economy. The majority of the buildings in this area are residential, and this situation also supports local trade. Expanding this to establish marketplaces for the agricultural products of nearby villages would be beneficial. However, traditional irregular shop windows and ragged shopfronts are among the problems to be solved before such a plan can be implemented. Another important issue is the absence of a proper fish market in the area, despite it being well known for its fishing industry.

\section{Potentials and Threats}

Despite the problems mentioned above, the existence of recoverable coastal lands and green areas are important potential boons to the study area. Although there are certain obvious areas for improvement, there are other, more complicated problems such as changing the original coastal line by land reclamation or land fill ${ }^{4}$ which is a clear threat to the sustainability and the authenticity of the coastal urban form, current over consumption of spring waters, and increasing sea pollution due to insufficient inspection of the waste produced by vessels transiting the Bosphorus; these complications will increase in severity as threats, if the necessary measures are not taken.

The large-scale boats and tankers that pass through the Bosphorus, especially those without pilots, create substantial risk to life, property, and the environment. Also, light pollution caused by the illumination of roads, streets, buildings, restaurants, and other places of entertainment along the coast of the Bosphorus obscure the navigation of vessels and cause accidents. Moreover, since it is located at the north entrance, Sariyer is one of the riskiest places for sea fires due to tanker accidents (Ece, 2006). Additionally, construction of a third bridge that now crosses the Bosphorus has already caused deforestation, and more severe harm to the natural and historic heritage of the area is likely to result due to an increase in the population. The direct and indirect effects of the third bridge extend

\footnotetext{
4 The intent for land reclamation or land fill on the coastal line of Bosphorus has a history. Different from the naturally debris filled Dolmabahçe Palace land which used to be a bay area for the Ottoman Navy ships and reused in the 17th century (URL12), the land reclamations on the Bosphorus do not occur as natural as the former. In the 1950s to connect the far Bosphorus villages with the city, in the late 1980 s and in the 2000 s to reduce the traffic congestion, the original coastal line was filled a few times and changed to enlarge the coastal roads, or to build new ports or squares for large public gatherings, mostly in an uncoordinated and uncontrolled way under the authority of different municipalities, preferred as the easiest way to solve problems. Apart from causing a clear problem of loss of original urban form and spatial qualities at the coastal line, these artificially filled coastal areas are against sustainability and highly risky. These areas collapse easily due to coastal erosions, ruin the living environment of shore creatures, disrupts the chemical properties of the sea water devastating its self-renewal mechanism, and accelerates the rise of the sea level which is already a problem related with climate change (URL13). Land reclamation or land fill must be a decision preferred only after a careful and common interdisciplinary evaluation.
}

to the agricultural lands nearby, which were opened up to construction activities. As a consequence, local agriculture may soon disappear.

\section{Conservation Proposals: Sustainability and Energy Efficiency \\ Environmental Scale}

On an environmental scale, it is necessary to decrease the amount of energy consumption and level of air pollution by traffic and motor vehicles. The primary solution to façade damage of historic buildings is to decrease the rate of private vehicles by stimulating the use of public transportation. Technological innovations must be pursued to accomplish this goal. For instance, by using electrical and hybrid buses, which are in use in many cities, carbon dioxide emissions can be decreased by up to $30 \%$, and noise pollution can be decreased by $3 \%$ (URL7). Also, the promotion of maritime transportation would be useful among the Bosphorus villages. In this context, Yenimahalle Pier could be reconstructed, depending on the approval of a restoration project by the Conservation Council and the availability of historical documents and photographs. Conversely, for short distance transportation, pedestrian movement must be encouraged by improving pedestrian walkways and sidewalks that follow universal design standards and consider handicapped people and babies in strollers. Both private cycling and public bike share programs must also be supported by providing necessary bicycle paths, itineraries, parking areas and stations at convenient locations in the area.

Renovations and repairs to the study area should emphasize energy efficiency and alternative energy sources. In 1987, a transition was made from coal and fuel oil, which caused excessive air pollution, to natural gas with some compelling precautions by the Governor's Office in 1993 for its widespread use. Today, natural gas is the most common energy source and heating system in Istanbul and Sarıyer, but quite an expensive one. For example, widespread adoption of air source heat pumps would lead to lower annual heating and cooling energy consumption, since the study area is located in a moderate climatic zone. An air source heat pump, which can be installed in a household garden, is a system of producing energy through the use of natural air. In this sense, the existence of frequent gardens in the study area is an advantage (Kaptanoğlu, 2014: 150). An alternative energy production is possible for the buildings located along the coastline of Yenimahalle and Sarıyer through the installation of a different type of heat pump system that uses seawater (Erdem, 2010: 20-21).

Solar energy, another renewable and clean energy source, has significant potential in Turkey. On average, 
Turkey sees 2,400 hours of sun per year; Sarıyer district sees 2,000 to 2,200 hours annually (URL8). By comparison, the average in Germany is 1,900 hours and 1,800 hours in Sweden; yet in both cases, $12 \%$ of the annual energy is supplied from renewable energy sources. For this reason, photovoltaic panels and solar collectors are recommended alternative systems for the collection of solar energy (Aykal, Gümüş, Özbudak Akça, 2009: 80). The provision of incentives by the state to pursue alternative energy sources is very important. In this context, there are many countries offering support for such pursuits, with policies for free installation or the reduction of initial investment costs. However, a way must be found to use these methods and products that does not disturb the original spirit of the historic buildings and site.

It is also necessary to make better use of the valuable natural spring water sources in the area, such as Sariyer Stream, flowing through the valley, as one of many streams in Sarıyer. Some of the old wells in the gardens that are fed from Sarıyer Stream have become desiccated, as the stream bed was filled and covered, due to its pollution with the sewage and also to make new roads and parks in the area (Kaptanoğlu, 2014: 35-36). This kind of an intervention is unfortunately quite popular in Turkey against all legal restrictions to gain new construction areas in the valuable parts of the city. Although it is known as clearly scientifically inappropriate when it is not totally necessary and causing highly dangerous floods during rainy seasons. With these reasons, studying together with the traffic engineers and hydrologists, revitalization of Sarıyer Stream, as an important natural component that originally shaped the urban and architectural characteristics of the neighborhood, is also believed to positively affect the waterways to the wells, allowing for an increase in the use of well water. However, it is necessary to encourage the controlled use of sources of spring water, since only a few (such as Kestane) are still in use in the study area today (Kaptanoğlu, 2014: 148-189). Regulations should be implemented to ensure the reuse of rainwater and grey water, which would take pressure off of the local springs. The reused water could be kept in reservoirs for suitable cleaning purposes and garden irrigation. The grey water obtained from domestic waste treatment which can be reused after it is passed through carbon filters, should be made mandatory in the common areas of public spaces (Girgin, 2014: 84). Municipality-sponsored studies regarding how to clean up the waste left by cargo and passenger ships, as well as the waste oil left by fishing boats passing through the Bosphorus should be continued. Since it is very difficult to clean up the fuel spread on the seawater and compensate for losses to property and life, it is far better to study ways of preventing environmental violations during transit passage.
Last, but not least, waste control regulations must be revised, as well as the provision of regional waste collection and treatment systems in the study area. In Sarıyer district, the recycling unit controls the collection of recyclables and manages the regular collection of packaging waste, paper, and plastic products. However, instead of trying to carry the waste to far locations with high shipping costs and collecting organic waste from household garbage to be used in energy production and/or agricultural fertilizer in nearby fields would be an excellent economic and ecological solution, as carried out in Europe, the US and many countries in the world. According to Environment Indicator Report of 2017 by European Environment Agency, some countries in Europe including Germany with the highest rate of $66 \%$ is followed by Austria, Slovenia, Switzerland, Belgium, Netherlands and Sweden at a rate of higher than 50\%; a total of 23 European countries with a rate of $30 \%$ or higher managed to recycle municipal waste for composting and digestion with an increasing performance since 2004, when Turkey's recycling rate stayed at an unchanged $1 \%$ (URL9). On the other hand, in the US, smaller cities like San Francisco (California), Portland (Oregon) and Seattle (Washington) started earlier and had quite similar mandatory programs to recycle food waste, then came New York City (or New York) which is a huge metropolis by means of population, started recycling food waste in 2013 , developing the largest program, aiming to include all city residents and the highest rate in the country (URL10). Since 2000, the World Bank started to finance and advise on many solid waste management projects in the countries like Indonesia, China, Azerbaijan, Argentina, Jamaica, Morocco, Nepal, Pakistan and Liberia, with the scope of building more sustainable and livable cities all around the world; using a diverse suite of products and services, including traditional loans, resultsbased financing and technical advisory (URL11). Apart from these, there are also other waste recycling management programs in service in Montreal, Canada and in Bangkok, Thailand to determine sustainable solutions to manage their solid wastes with the beneficial results in pollution control, energy recovery and reduction of greenhouse gas emission to the atmosphere (Polprasert, 2007: 503-506).

Regarding the maritime traffic on the Bosphorus, due to the 1936 Montreux Convention and 1998 Turkish Straits Marine Traffic Regulations, it is specifically recommended (but not compulsory) to use a pilot during an uninterrupted passage of the Turkish Straits (the Bosphorus and the Dardanelles); the absence of a pilot creates a high risk of accident with other vessels. It also poses dangers to the natural and built environments. Apart from the overtly destructive consequences of these policies, it is very difficult to clean up waste from ships deposited in this environment. For this reason, precautions should be taken to prevent these types of passages through the Bosphorus. Experts recom- 
mend safety checks such as the use of a pilot and escort tug boat for transit ships, being one of the riskiest places along Bosphorus for sea fires from tanker accidents. Light pollution along the Bosphorus must also be prohibited to provide full view to ships so they can better avoid accidents.

\section{Architectural Scale ${ }^{5}$}

In sustainable architecture, choice of materials is critical. Building energy consumption and preservation of natural sources are especially important for the protection of users and the environment. Construction materials should consume a minimum amount of energy and the extraction, processing, use, maintenance and waste production from raw materials should not harm humans or the environment (Sayar, Gültekin, \& Dikmen, 2009). In the study area, it was observed that the original timber windows and doors of some traditional buildings were replaced with PVC (polyvinylchloride). Higher heat capacity, double-glass use, and easy maintenance make PVC desirable. Yet, PVC is listed as a human carcinogen at many public health reports and thus should not be used (despite being among the most widespread materials used in Turkey). In that sense, problematic wooden elements should be replaced with environmentally sensitive, certified forest products, instead of PVC. Although the certification of wooden materials has just begun in Turkey, their use should be promoted (Kaptanoğlu, 2014: 164). In "Principles for the Preservation of Historic Timber Structures" published by ICOMOS in 1999, this issue is highlighted as follows: "The establishment and protection of forest or woodland reserves where appropriate timber can be obtained for the preservation and repair of historic timber structures should be encouraged" (Ahunbay, 2012: 43).

Additionally, painting the timber façades of buildings prevents the harmful effects of sunbeams, air pollution, heat, moisture, and dampness. It also contributes to the preservation of load-bearing timber materials beneath the façade's coating. For this purpose, use of traditional paints such as linseed oil, oil paint, under-coating, ochre, and state-of-the-art water vapour-permeable paints with five to seven years of durability are recommended (Günay, 2007: 48-49, 245). All of these solutions for structural problems require a minimum level of intervention. What is called "passive" conservation systems today, include the use of natural air conditioning, improvement in construction materials, and the active use of natural lighting.

Traditional buildings constructed via original building techniques have offered healthy and thermally-comfortable conditions to inhabitants for more than a century.

\footnotetext{
5 The proposals are developed, based on the analysis and evaluation of the single historic residential building at Ortaceşme Street No: 47 (at Fig. 11

[2]) chosen as a sample from the study area, which has a composite structural system, composed of brick masonry and timber skeleton, which is the most common structural system for historic buildings in the study area.
}

However, both to ensure continuity in traditional buildings and obtain data for use in sustainable new-construction architectural projects, studies should be conducted that, in addition to identifying the materials, components, and construction techniques of traditional buildings, analyse natural air conditioning systems and heat capacity properties.

Active energy consumption is usually decreased to a minimum in traditional buildings via interior spatial organization, positioning on the building lot, and construction materials chosen to work well with the building's climate, external temperature, moisture, solar radiation, and wind. A number of academic studies have been conducted on this topic at different regions of Turkey. Although they were performed on traditional buildings with different construction techniques and in a variety of climatic conditions, the results have shown their performance to be close to the standard. A similar multidisciplinary study on traditional buildings on the Bosphorus University campus would be an important contribution to conservation research.

\section{Conclusion}

Located near the north forests of Turkey, Sariyer consitutes an important part of the green structure and the ecological corridor of the city, also being a major source of fresh air in Istanbul. On the other hand, Sariyer District comprising Sarıyer and Yenimahalle historic areas, once being isolated and away from the city center, still carries the unique characteristics of a Bosphorus village, reflecting a culture of its original historic, cultural and natural qualities in its modest, warm and tranquil style. On the other hand, the natural and built heritage is under the great pressure, as it became a part of a metropolitan city under the negative impacts of continuous population increase and huge urban developments. Although some of the authentic qualities have been recently lost, there are many others left that are in dire need of protection.

Parallel to the aim of this study, the analyses, evaluation and proposals are put forward to conserve this built environment with its large stock of historic buildings and its distinctive urban characteristics to improve the overall quality of life as a former Bosphorus village. But, beyond that, architectural and urban conservation issues are tried to be handled in a multi-faceted way as much as possible, and emphasized through an understanding of sustainability and energy efficiency to respond to this major global concern, developing recommendations for healthier environments in a more permanent sense.

Although Turkey participates in the related mutual agreements and processes, the results show that our country performance is far behind the other (EU) countries in terms of energy efficiency and sustainability, and there is a lot to be done especially in built environments, 
of which the field of conservation constitutes an important and critical part of it. For more livable environments, it is believed that an interdisciplinary scientific approach must be preferred for more holistic and comprehensive solutions with a more decisive country attitude.

\section{References}

2010-2013 İstanbul Bölge Planı Ekleri, İstanbul Kalkınma Ajansı, November 2011.

Ahunbay, Z. (2012), "Ahşap Yapıların Korunması Ile Illgili Uluslararası Illkelere Türkiye'den Bakış", Ahşap Yapılarda Koruma ve Onarım Sempozyumu Bildiri Kitabı, KUDEB, İstanbul.

Aykal, D., F., Gümüş, B., Özbudak Akça, B., Y. (2009), "Sürdürülebilirlik Kapsamında Yenilenebilir ve Etkin Enerji Kullanımının Yapılarda Uygulanması", 5. Yenilenebilir Enerji Kaynakları Sempozyumu, Diyarbakır.

Balcı, i. (1998), Sarıyer'i Görmek ve Hissetmek, Cem Ofset Matbaacılık Sanayi A.Ş., İstanbul.

Balcı, i. (2006), Sarıyer, Aşiyan'dan Kısırkaya'ya, İlkbiz Yayınevi, istanbul.

Baycan Levent, T., (1999), Sürdürülebilir Bölgesel Kalkınma: Marmara Havzası İçin Bir Yöntem Denemesi, Ph.D. Dissertation in City and Regional Planning, iTÜ, İstanbul.

Beyhan, Ş., G., (2004), Kültürel Sürdürülebilirlik ve Çağdaş Gereksinimler Bağlamında Sürdürülebilir Turizm ve Kimlik Kavramsal Modeli: Pamukkale Örneği, Ph.D. Dissertation in Architecture, iтü, i̇stanbul.

Deringil, S. (2006), "Bosphorus", Europe 1789-1914: Encyclopedia of the Age of Industry and Empire (ed. John Merriman and Jay Winter), Vol. 1. Detroit: Charles Scribner's Sons, pp.277-279.

Doğan E., Burak S. (2007), Ship Originated Pollution in the Istanbul Strait (Bosphorus) and Marmara Sea, Journal of Coastal Research, Vol. 23, No.2 (March 2007), pp.388-394.

Dresner, S. (2002), The Principles of Sustainability, Earthscan Publications, London.

Ece, J. N. (2006) İstanbul Boğazı'nda Seyir ve Çevre Güvenliği, Kaptan Haber, http://www.kaptanhaber.com/kose-yazisi/100110/ Istanbul-bogazinda-seyir-ve-cevre-guvenligi.html.

Egelston, A. E. (2013), Sustainable Development: A History, Springer, Dordrecht.

Erdem, B. (2010), Binalarda Enerji Korunumu Açısından Isı Pompalarının Farklı İklim Bölgelerinde Uygulanması, Masteris Thesis on Architecture, iTü, ìstanbul.

Fabbri, K., Zuppiroli, M., Ambrogio, K. (2012), Heritage Buildings and Energy Performance: Mapping with GIS Tools, Energy and Buildings, Volume 48, pp. 137-145, Elsevier.

Fawkes, S. (2013) Energy Efficiency, The Definitive Guide to the Cheapest, Cleanest, Fastest Source of Energy, Taylor and Francis, Farnham, Surrey, England: Gower.

Genim, S. (2000), Konstantiniyye'den Istanbul'a 19. Yüzyıl Ortalarından 20. Yüzyılda Bosphorus'nin Rumeli Yakası Fotoğrafları, Suna ve Inan Kıraç Vakfi İstanbul Araştırmaları Enstitüsü Kataloglar Dizisi, İstanbul.

Girgin, E. (2014), Güncel Dosya: “Kuraklık Kapıda mı?”, Yapı Dergisi, No: 394, ìstanbul.

Günay, Z. (2010), Neoliberal Kentleşme Dinamikleri Çerçevesinde Tarihi Çevrenin Sürdürülebilirliği: Sürdürülebilir Kentsel Koruma Modeli, Şehir ve Bölge Planlama Ana Bilim Dalı Doktora
Tezi, iTü, İstanbul.

Günay, R. (2007), Geleneksel Ahşap Yapılar, Sorunları ve Çözüm Yolları, Birsen Yayınevi, i̇stanbul.

Hürel, H. (2010), İstanbul'un Ansiklopedik Öyküsü, Kapı Publications, ìstanbul.

İnciciyan, G. V. (2000), Boğaziçi Sayfiyeleri, Eren Yayıncılık, İstanbul.

Kaptanoğlu, i.z. (2014), İstanbul-Sarıyer'de Tarihi Dokunun Sürdürülebilir Koruma Ölçütleri Açısından İredelenmesi ve Öneri Geliştirilmesi, unpublished master's thesis, Graduate Program in Architectural History and Restoration, Istanbul Kültür University, Istanbul, p. 243, Thesis supervisor: Assist. Prof. Dr. Elif Mıhçığlu Bilgi.

Kuban, D. (2010), Kent ve Mimarlık Üzerine İstanbul Yazıları, Yem Yayın, İstanbul.

Mantran, R. (2005), İstanbul Tarihi, Iletişim Yayınları, İstanbul.

Mazak, A., Mazak, M. (2008), Dersaadet'in Sayfiye Semti Sarıyer, Sarıer Belediyesi, ìstanbul.

Polprasert, C. (2007), Organic Waste Recycling: Technology and Management, IWA Publishing, London, UK, ISBN: $183339121 X$.

Rodwell, D. (2003), Sustainability and the Holistic Approach to the Conservation of Historic Cities, Journal of Architectural Conservation, 9:1, 58-73.

Sayar, Z., Gültekin, A., B., Dikmen, Ç. B. (2009), "Sürdürülebilir Mimarlık Kapsamında Ahşap ve PVC Doğramaların Değerlendirilmesi", 5. Uluslararası İleri Teknolojiler Sempozyumu ('ATS'09), Karabük.

Sumner-Boyd, H.; Freely, J. (2010), Strolling Through Istanbul: The Classic Guide to The City, London: Tauris Parke Paperbacks.

Tutel, E. (2008), Şirket-i Hayriye, iletişim Yayınları, İstanbul.

Ülgen, A. (1996) Istanbul Armagani 2: Boğaziçi Medeniyeti, pp.127-146, İstanbul Greater City Municipality, İstanbul.

Yılmaz Özbağcı, Ş., San Akça B., Türkay M. (2013), Energy Efficiency Map of Turkey and Goals, Koç Üniversitesi Tüpraş Enerji Merkezi, Istanbul.

\section{Internet Sources}

URL1:http://www.forumforthefuture.org/sites/default/files/ images/Forum/Projects/Sustainable_Cities_Index/sustainablecities07.pdf, February 2014.

URL2: http://www.enerjikimlikbelgesi.com, March 2017.

URL3: http://www.panoramio.com/photo/96913949, March 2017.

URL4: http://mapio.net/pic/p-96991360/, March 2017.

URL5: http://www.envanter.gov.tr, May 2014.

URL6: http://iljandarma.Istanbul.gov.tr, March 2017.

URL7: http://www.tfl.gov.uk, May 2014.

URL8: http://www.eie.gov.tr, May 2014.

URL9:https://www.eea.europa.eu/airs/2017/resource-efficiency-and-low-carbon-economy/recycling-of-municipal-waste, August 2018.

URL10: https://www.nytimes.com/2017/06/02/nyregion/compost-organic-recycling-new-york-city.html, August 2018.

URL11:http://www.worldbank.org/en/topic/urbandevelopment/ brief/solid-waste-management, pp.503-504, August 2018.

URL12:http://www.istanbul.com/tadini-cikar/dolmabahce-dolgu-deniz-ve-has-bahce.html, August 2018.

URL13:http://www.cumhuriyet.com.tr/koseyazisi/470550/ Denizi_doldurmak_mi_insanlik_sucu.html, August 2018. 